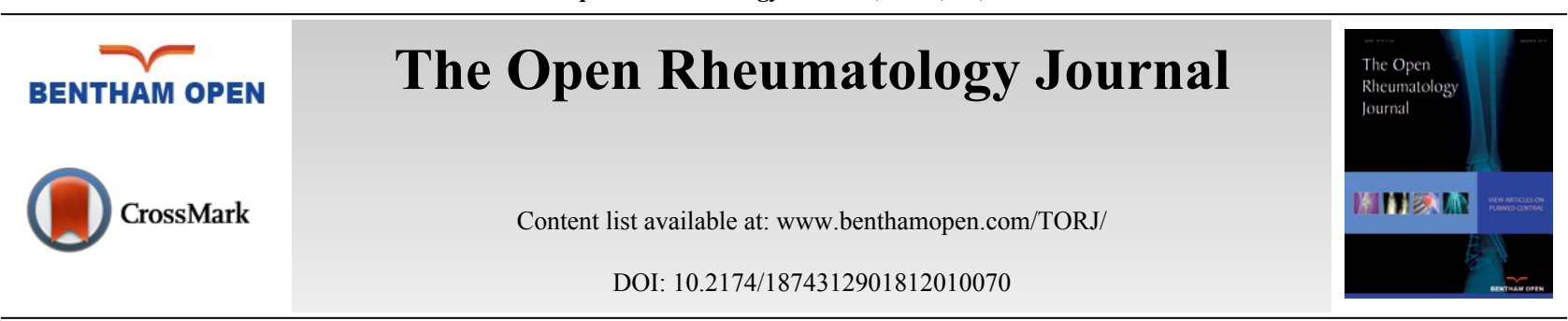

Systematic Review

\title{
Immune Regulatory Genes Are Major Genetic Factors to Behcet Disease: Systematic Review
}

\author{
Yan Deng ${ }^{1,2}$, Weifeng $\mathrm{Zhu}^{2,3}$ and Xiaodong Zhou, ${ }^{2, *}$ \\ ${ }^{I}$ The Second Affiliated Hospital of Nanchang University, Nanchang, China \\ ${ }^{2}$ Department of Internal Medicine/Rheumatology, University of Texas Health Science Center at Houston McGovern \\ Medical School, Houston, USA \\ ${ }^{3}$ College of Basic Medical Sciences, Nanchang University, Nanchang, China
}

Received: March 13, 2018

Revised: May 4, 2018

Accepted: June 4, 2018

\begin{abstract}
Behcet's disease (BD) is a chronic refractory multi-system autoimmune disorder that occurs in a genetically susceptible host. Multiple genetic factors have been identified that may contribute to the pathogenesis of BD. The major genes with polymorphisms associated with BD include HLA-B and -A, CIITA, ERAP1, MICA, IL10, IL12A, IL12RB2, IL23R, MEFV, IRF8, TNFAIP3, REL, TLR4, NOD1,2, CCR1,CCR3, GIMAP1,2,4, KLRC4, STAT4, NCOA5, FOXP3, PSORS1C1, FUT2, UBAC2, SUMO4, ADO-EGR2, CEBPB-PTPN1, and JPKL-CNTN5. These genes encode proteins involved mainly in immune regulation and inflammation, and some in transcription and post-translational modification. A complete view of these BD-associated genes may provide a clue to this complex disease in terms of its pathogenesis and exploring potentially targeted therapies for BD.
\end{abstract}

Keywords: Behcet's disease, genetic association, HLA, MICA, CIITA, ERAPI.

\section{INTRODUCTION}

Behcet's Disease (BD) is a chronic inflammatory disorder, characterized by refractory genital and oral ophthous ulcers, uveitis, skin lesions, and manifestations in other systems including gastrointestinal tract, central nervous system, vascular system, joints, kidneys, and lungs [1]. BD was found primarily in populations along the ancient silk Route from the Mediterranean Basin across Asia to Japan [2]. The prevalence of BD was reported to vary widely in Western (0.12-7.5 per 100,000) [3] and Eastern countries (6.3-14 per 100,000) [4], which may be due to ethnic disparities, and risk factors. The highest incidence was reported in Turkey from 80 to 420 per 100,000 population [5 - 7]. Positive history of $\mathrm{BD}$ in families is $31.2 \%$ [8], which indicates genetic contribution to the disease by comparing to general population. The male-to-female ratio was reported from 1.22 to 1 [9]. An association was found between the male gender and vascular lesions [10]. The first reported genetic association of BD was found in the Human Leukocyte Antigen (HLA) region in the Japanese population [11]. HLA-B51 appears to be the most strongly associated known genetic risk to BD [12]. However, it accounts for less than $20 \%$ of the overall genetic risk, which suggests that other genetic factors are also important. Here we review genetic studies of BD reported from 1973 to January 2018. A complete list of BD-associated genes and genetic loci are summarized in Table $\mathbf{1 .}$

A comprehensive search was conducted on PubMed, Embase, Web of Science, and the HuGE Navigator databases. The PubMed and Embase database were searched by a combination of MeSH, Emtree headings and text words. Exclusion criteria included case reports, studies with duplicate data, and non-English language papers.

\footnotetext{
* Address correspondence to this author at the Department of Internal Medicine/Rheumatology, University of Texas Health Science Center at Houston McGovern Medical School, Houston, USA; Tel: 713-500-6088; E-mail: xiaodong.zhou@uth.tmc.edu
} 
Table 1. Summary of BD associated genes

\begin{tabular}{|c|c|c|c|c|c|c|c|c|c|}
\hline Category & Gene & Variant & Location & $\begin{array}{c}\text { Associated } \\
\text { allele }\end{array}$ & $\begin{array}{c}\text { Strongest p } \\
\text { value }\end{array}$ & OR & Population & - & Reference \\
\hline- & - & - & - & - & - & - & Discovery & Replication & \\
\hline \multirow{23}{*}{$\begin{array}{l}\text { HLA and } \\
\text { related genes }\end{array}$} & \multirow{14}{*}{ HLA } & & \multirow[t]{8}{*}{ HLA-B } & 51 & $6.8 * 10-32$ & 20.64 & Japanese & $\begin{array}{c}\text { Spanish, } \\
\text { Chinese, } \\
\text { Korean, } \\
\text { Italian, } \\
\text { Turkish, } \\
\text { Ireland, } \\
\text { Russia, } \\
\text { Germen, } \\
\text { Greek, } \\
\text { Saudi, } \\
\text { Iranian, } \\
\text { Jordanian, } \\
\text { Tunisian, } \\
\text { Israeli }\end{array}$ & $16-33$ \\
\hline & & & & 15 & 0.03 & 0.254 & Saudi & Spanish & 26,33 \\
\hline & & & & 18 & 0.02 & 0.58 & Spanish & - & 26,28 \\
\hline & & & & 27 & 0.003 & 5.59 & Moroccan & - & 30 \\
\hline & & & & 35 & $2.46 * 10-8$ & 0.58 & Spanish & - & 26,28 \\
\hline & & & & 49 & $2.46 * 10-8$ & 0.7 & Spanish & - & 26 \\
\hline & & & & 57 & $1.02 * 10-5$ & 2.8 & Spanish & - & 26,28 \\
\hline & & & & 58 & 0.007 & 0.1 & Spanish & - & 28 \\
\hline & & & \multirow{6}{*}{ HLA-A } & 2 & 0.003 & 1.47 & Spanish & Korean & $26,28,36$ \\
\hline & & & & 3 & 0.003 & 0.53 & Spanish & - & 26,28 \\
\hline & & & & 24 & 0.01 & 1.7 & Spanish & - & 28 \\
\hline & & & & 26 & 0.025 & 3.87 & Spanish & $\begin{array}{c}\text { Saudi, } \\
\text { Japanese, } \\
\text { Korean }\end{array}$ & $26,32,33,34,35,36$ \\
\hline & & & & 30 & 0.003 & 7.53 & Korean & Spanish & 26,36 \\
\hline & & & & 31 & 0.089 & 4.06 & Spanish & - & 26,33 \\
\hline & CIITA & rs12932187 & Intron & $\mathrm{C}$ & 0.01668 & 0.713 & Han Chinese & - & 39 \\
\hline & \multirow{3}{*}{ ERAP1 } & rs 10050860 & Exon & $\mathrm{C}$ & $1.1 * 10-5$ & 0.54 & Han Chinese & - & 41 \\
\hline & & $\begin{array}{c}\text { rs17482078 } \\
\text { (Arg725Gln) }\end{array}$ & Exon & $\mathrm{C}$ & $4.73 * 10-11$ & 4.56 & Turkish & Iranian & 40,100 \\
\hline & & rs1065407 & 3'-UTR & $\mathrm{A}$ & $8.5 * 10-8$ & 0.51 & Han Chinese & - & 41 \\
\hline & \multirow{5}{*}{ MICA } & \multirow{5}{*}{ - } & \multirow{5}{*}{ Exon } & MICA*009 & 0.0009 & 2.82 & Spanish & - & 42 \\
\hline & & & & $* 019$ & 0.0007 & 6.48 & Spanish & - & 42 \\
\hline & & & & A5.1 & $<0.001$ & 0.18 & Korean & - & 49,50 \\
\hline & & & & A6 & $6 * 10-5$ & 2.47 & Japanese & $\begin{array}{c}\text { Korea, } \\
\text { Jordanian, } \\
\text { Greek }\end{array}$ & $47,48,49,51$ \\
\hline & & & & A9 & 0.0009 & 2.82 & Japanese & - & 51 \\
\hline \multirow[b]{2}{*}{$\begin{array}{l}\text { IL family } \\
\text { genes }\end{array}$} & \multirow[b]{2}{*}{ IL10 } & rs 1518111 & Intron & A & $1.88 * 10-8$ & 1.41 & Turkish & $\begin{array}{l}\text { Iranian, } \\
\text { Korean, } \\
\text { Japanese, } \\
\text { Chinese }\end{array}$ & $56,68,70$ \\
\hline & & rs1800871 & Upstream & $\mathrm{T}$ & $1.0 * 10-14$ & 1.45 & Japanese & $\begin{array}{c}\text { Turkish, } \\
\text { Korean, } \\
\text { Han } \\
\text { Chinese, } \\
\text { Western } \\
\text { Algeria }\end{array}$ & $55,57,66,69,70$ \\
\hline
\end{tabular}




\begin{tabular}{|c|c|c|c|c|c|c|c|c|c|}
\hline Category & Gene & Variant & Location & $\begin{array}{l}\text { Associated } \\
\text { allele }\end{array}$ & $\begin{array}{l}\text { Strongest p } \\
\text { value }\end{array}$ & OR & Population & - & Reference \\
\hline \multirow{13}{*}{$\begin{array}{l}\text { IL family } \\
\text { genes }\end{array}$} & \multirow[t]{2}{*}{ IL10 } & rs 1800872 & Upstream & A & $2.1 * 10-14$ & 1.64 & Japanese & $\begin{array}{l}\text { Turkish, } \\
\text { Korean, } \\
\text { Han } \\
\text { Chinese, } \\
\text { Western } \\
\text { Algeria }\end{array}$ & $55,57,66,69,70$ \\
\hline & & rs 1554286 & Intron & $\mathrm{T}$ & $3.15 * 10-5$ & 0.558 & Iranian & $\begin{array}{c}\text { Korean, } \\
\text { Han Chinese }\end{array}$ & $55,66,68,70$ \\
\hline & \multirow[t]{2}{*}{ IL12A } & rs17810546 & Intron & G & $1.12 * 10-10$ & 1.66 & $\begin{array}{c}\text { Turkish, } \\
\text { Mixed } \\
\text { population }\end{array}$ & - & 41,61 \\
\hline & & rs 17810458 & Intron & G & $1.20 * 10-5$ & 1.64 & Turkish & European & 61 \\
\hline & \multirow{7}{*}{ IL23R-IL12RB2 } & rs1495965 & Intergenic & G & $1.9 * 10-11$ & 1.35 & Japanese & $\begin{array}{l}\text { Turkish, } \\
\text { Iranian, } \\
\text { Korean }\end{array}$ & $57,68,70$ \\
\hline & & rs924080 & Intergenic & $\mathrm{T}$ & $2.52 * 10-4$ & 1.58 & Turkish & $\begin{array}{c}\text { Japanese, } \\
\text { Han } \\
\text { Chinese, } \\
\text { Korean, } \\
\text { Iranian, } \\
\text { Western } \\
\text { Algeria }\end{array}$ & $56,67-70$ \\
\hline & & rs11209032 & Intergenic & A & $3.46 * 10-4$ & 1.45 & Han Chinese & $\begin{array}{l}\text { Western } \\
\text { Algeria }\end{array}$ & 67,69 \\
\hline & & rs 17375018 & Intron & G & 0.017 & 1.51 & Iranian & - & 68 \\
\hline & & rs7517847 & Intron & $\mathrm{T}$ & $1.96 * 10-6$ & 1.48 & Iranian & - & 68 \\
\hline & & rs10489629 & Intron & G & 0.0017 & 0.77 & Iranian & - & 68 \\
\hline & & rs1966176 & Intron & G & 0.0026 & 1.8 & Korean & - & 70 \\
\hline & \multirow{2}{*}{ IL23R } & $\begin{array}{c}\text { rs11209026 } \\
\text { (Arg381Gln ) }\end{array}$ & Exon & Gln & $8.49 * 10-9$ & 0.68 & $\begin{array}{l}\text { Turkish, } \\
\text { Japanese }\end{array}$ & - & 65 \\
\hline & & $\begin{array}{l}\text { rs76418789 } \\
\text { (Gly149Arg) }\end{array}$ & Exon & Arg & 0.022 & 0.54 & $\begin{array}{l}\text { Turkish, } \\
\text { Japanese }\end{array}$ & - & 65 \\
\hline \multirow{18}{*}{$\begin{array}{c}\text { Genes } \\
\text { involved in } \\
\text { inflammation } \\
\text { and } \\
\text { autoimmunity }\end{array}$} & \multirow{3}{*}{ MEFV } & $\begin{array}{c}\text { rs61752717 } \\
\text { (Met694Val) }\end{array}$ & Exon & Val & $1.79 * 10-12$ & 2.65 & $\begin{array}{c}\text { Mixed } \\
\text { populations }\end{array}$ & $\begin{array}{c}\text { Turkish, } \\
\text { Spanish, } \\
\text { Greek }\end{array}$ & $65,73-76$ \\
\hline & & $\begin{array}{l}\text { rs28940580 } \\
\text { (Met680Ile) }\end{array}$ & Exon & Ile & 0.046 & 1.74 & Turkish & $\begin{array}{c}\text { Spanish, } \\
\text { Greek }\end{array}$ & $65,74-76$ \\
\hline & & $\begin{array}{c}\text { rs3743930 } \\
\text { (Glu148Gln) }\end{array}$ & Exon & Gln & 0.001 & 3.6 & $\begin{array}{c}\text { Mixed } \\
\text { populations }\end{array}$ & $\begin{array}{c}\text { Turkish, } \\
\text { Spanish, } \\
\text { Greek }\end{array}$ & $65,73-75$ \\
\hline & \multirow{5}{*}{ IRF8 } & rs17445836 & Downstream & $\mathrm{G}$ & $9.56 * 10-8$ & 2.044 & \multirow{2}{*}{ Han Chinese } & - & 79 \\
\hline & & rs11642873 & Downstream & A & $9.24 * 10-7$ & 1.776 & & - & 79 \\
\hline & & rs11117433 & Intron & $\mathrm{C}$ & $1.67 * 10-6$ & 0.63 & \multirow{3}{*}{ Turkish } & Iranian, & \multirow{3}{*}{80} \\
\hline & & rs142105922 & Intergenic & $\mathrm{A}$ & $5.58 * 10-6$ & 0.63 & & Japanese & \\
\hline & & rs7203487 & Intergenic & $\mathrm{C}$ & $1.1 * 10-6$ & 1.38 & & Iranian & \\
\hline & \multirow{3}{*}{ TNFAIP3 } & rs9494885 & Intergenic & $\mathrm{C}$ & $8.35 * 10-10$ & 1.81 & \multirow{3}{*}{ Han Chinese } & \multirow{3}{*}{-} & 85 \\
\hline & & rs10499194 & Intergenic & $\mathrm{T}$ & 0.015 & 1.96 & & & 85 \\
\hline & & rs 7753873 & Intergenic & $\mathrm{C}$ & 0.015 & 1.49 & & & 85 \\
\hline & REL & rs842647 & Intron & G & 0.0074 & 1.57 & Chinese & - & 90 \\
\hline & \multirow{3}{*}{ TLR4 } & $\begin{array}{c}\text { rs4986790 } \\
\text { (Asp299G1) }\end{array}$ & Exon & G & $8.0 * 10-12$ & 0.64 & Japanese & \multirow{2}{*}{$\begin{array}{l}\text { Turkish, } \\
\text { Korean, } \\
\text { Chinese }\end{array}$} & $65,93,94$ \\
\hline & & $\begin{array}{c}\text { rs4986791 } \\
\text { (Thr399Ile) }\end{array}$ & Exon & $\mathrm{T}$ & $8.0 * 10-12$ & 0.82 & Japanese & & $65,93,94$ \\
\hline & & rs7037117 & 3'-UTR & A & 0.009 & 1.64 & Japanese & Korean & $92-94$ \\
\hline & \multirow{2}{*}{ TLR2 } & rs 2289318 & Intron & $\mathrm{C}$ & $6.99 * 10-6$ & 1.47 & Chinese & - & 94 \\
\hline & & rs3804099 & Exon & $\mathrm{C}$ & $2.43 * 10-6$ & 0.626 & Chinese & - & 94 \\
\hline & NOD1 & rs 2075818 & Exon & G & 0.0102 & 0.536 & Han Chinese & - & 39 \\
\hline
\end{tabular}




\begin{tabular}{|c|c|c|c|c|c|c|c|c|c|}
\hline Category & Gene & Variant & Location & $\begin{array}{l}\text { Associated } \\
\text { allele }\end{array}$ & $\begin{array}{l}\text { Strongest } p \\
\text { value }\end{array}$ & OR & Population & - & Reference \\
\hline \multirow{14}{*}{$\begin{array}{c}\text { Genes } \\
\text { involved in } \\
\text { inflammation } \\
\text { and } \\
\text { autoimmunity }\end{array}$} & \multirow{3}{*}{ NOD2 } & $\begin{array}{c}\text { rs2066844 } \\
\text { (Arg702Trp) }\end{array}$ & Exon & Arg & $1.35 * 10-5$ & 0.4 & Caucasians & \multirow{3}{*}{$\begin{array}{l}\text { Japanese, } \\
\text { Turkish, } \\
\text { Spanish }\end{array}$} & $65,100,102$ \\
\hline & & $\begin{array}{c}\text { rs2066847 } \\
\text { (Leu1007fs) }\end{array}$ & Exon & $\mathrm{C}$ & 0.0069 & 0.38 & $\begin{array}{c}\text { Japanese, } \\
\text { Turkish }\end{array}$ & & 65,100 \\
\hline & & $\begin{array}{c}\text { rs2066845 } \\
\text { (Gly908Arg) }\end{array}$ & Exon & Gly & NA & NA & $\begin{array}{c}\text { Japanese, } \\
\text { Turkish }\end{array}$ & & 65 \\
\hline & \multirow{4}{*}{$\begin{array}{l}\text { CCR1 and } \\
\text { CC1/CCR3 }\end{array}$} & rs13084057 & Intron & G & $1.71 * 10-7$ & 0.32 & \multirow{3}{*}{ Han Chinese } & \multirow{3}{*}{-} & \multirow{3}{*}{103} \\
\hline & & rs13075270 & Intron & $\mathrm{C}$ & $2.76 * 10-7$ & 0.32 & & & \\
\hline & & rs13092160 & Intron & $\mathrm{C}$ & $6.50 * 10-8$ & 0.28 & & & \\
\hline & & rs7616215 & Intron & $\mathrm{T}$ & $5.05 * 10-19$ & 0.66 & $\begin{array}{l}\text { Turkish, } \\
\text { Japanese }\end{array}$ & Iranian & 40,104 \\
\hline & GIMAP1 & rs 2286900 & Intron & A & $9.22 * 10-6$ & 1.81 & $\begin{array}{l}\text { Korean, } \\
\text { Japanese }\end{array}$ & - & \multirow{6}{*}{107} \\
\hline & \multirow{2}{*}{ GIMAP2 } & rs10266069 & Upstream & A & $2.57 * 10-5$ & 1.83 & \multirow{2}{*}{$\begin{array}{l}\text { Korean, } \\
\text { Japanese }\end{array}$} & - & \\
\hline & & rs10256482 & Upstream & $\mathrm{T}$ & $2.82 * 10-5$ & 1.83 & & - & \\
\hline & \multirow{3}{*}{ GIMAP4 } & rs1916012 & Upstream & $\mathrm{A}$ & $2.62 * 10-2$ & 1.61 & \multirow{3}{*}{$\begin{array}{l}\text { Korean, } \\
\text { Japanese }\end{array}$} & - & \\
\hline & & rs 1522596 & Upstream & $\mathrm{A}$ & $3.43 * 10-7$ & 2.38 & & - & \\
\hline & & rs1608157 & Intron & $\mathrm{C}$ & $6.01 * 10-8$ & 2.53 & & - & \\
\hline & KLRC4 & rs 2617170 & Exon & $\mathrm{T}$ & $7.98 * 10-7$ & 0.71 & $\begin{array}{l}\text { Turkish, } \\
\text { Japanese }\end{array}$ & Iranian & 40,104 \\
\hline \multirow{5}{*}{$\begin{array}{l}\text { Genes } \\
\text { involved in } \\
\text { transcription } \\
\text { activation of } \\
\text { immune } \\
\text { regulation }\end{array}$} & \multirow{3}{*}{ STAT4 } & rs7572482 & Intron & $\mathrm{T}$ & $9.77 * 10-5$ & 1.68 & Han Chinese & - & 112 \\
\hline & & rs 7574070 & Intron & $\mathrm{T}$ & $1.92 * 10-5$ & 1.27 & Turkish & Iranian & $40,104,112$ \\
\hline & & rs897200 & Intron & $\mathrm{A}$ & $5.88 * 10-5$ & 1.7 & Han Chinese & - & 112 \\
\hline & NCOA5 & rs2903908 & Intron & $\mathrm{T}$ & 0.016 & 1.46 & $\begin{array}{c}\text { Mixed } \\
\text { populations }\end{array}$ & - & 115 \\
\hline & FOXP3 & rs 3761548 & Intron & $\mathrm{A}$ & 0.002 & 3.841 & Iranian & - & 118 \\
\hline \multirow{20}{*}{ Others } & PSORS1C1 & rs 12525170 & Intron & G & $3.01 * 10-26$ & 3.01 & $\begin{array}{l}\text { Turkish, } \\
\text { Italian }\end{array}$ & - & 124 \\
\hline & \multirow{6}{*}{ FUT2 } & rs632111 & 3'-UTR & $\mathrm{G}$ & $2.09 * 10-5$ & 1.32 & \multirow{6}{*}{ Iranian } & \multirow{6}{*}{ Turkish } & \multirow{6}{*}{128} \\
\hline & & rs601338 & Exon & A & $1.18 * 10-5$ & 1.34 & & & \\
\hline & & rs602662 & Exon & $\mathrm{A}$ & $2.97 * 10-6$ & 1.35 & & & \\
\hline & & rs492602 & Exon & $\mathrm{C}$ & $4.86 * 10-5$ & 1.31 & & & \\
\hline & & rs681343 & Exon & $\mathrm{T}$ & $7.27 * 10-6$ & 1.36 & & & \\
\hline & & rs281377 & Exon & $\mathrm{C}$ & $1.34 * 10-4$ & 1.3 & & & \\
\hline & \multirow{6}{*}{ UBAC2 } & rs9513584 & Intron & G & 0.0058 & 1.61 & Turkish & Han Chinese & 130,132 \\
\hline & & rs7999348 & Intron & $\mathrm{G}$ & 0.00058 & 1.84 & Turkish & - & 132 \\
\hline & & rs 3825427 & Intron & $\mathrm{T}$ & $6.9 * 10-6$ & 1.5 & Han Chinese & - & 132 \\
\hline & & rs9517668 & Intron & $\mathrm{T}$ & $3.3 * 10-4$ & 1.4 & Han Chinese & - & 132 \\
\hline & & rs9517701 & Intron & G & $2.9 * 10-5$ & 1.4 & Han Chinese & - & 132 \\
\hline & & rs9517723 & Intron & $\mathrm{T}$ & 0.0024 & 1.56 & Japanese & - & 133 \\
\hline & \multirow{2}{*}{ SUMO4 } & rs237024 & Intron & $\mathrm{A}$ & 0.0002 & 1.7 & \multirow{2}{*}{ Han Chinese } & \multirow{2}{*}{$\begin{array}{l}\text { Tunisian, } \\
\text { Korean }\end{array}$} & 136-138 \\
\hline & & rs237026 & Intron & $\mathrm{C}$ & 0.03 & 1.41 & & & 136,137 \\
\hline & \multirow{3}{*}{ ADO-EGR2 } & rs 7075773 & Intergenic & $\mathrm{C}$ & $2.96 * 10-9$ & 0.71 & & - & \\
\hline & & rs224127 & Intergenic & A & $1.56 * 10-6$ & 1.26 & Turkish & Iranian, & 80 \\
\hline & & rs1509966 & Intergenic & $\mathrm{A}$ & $1.47 * 10-6$ & 0.8 & & Japanese & \\
\hline & CEBPB-PTPN1 & rs913678 & Intergenic & $\mathrm{C}$ & $1.1 * 10-9$ & 1.33 & Turkish & Iranian & 80 \\
\hline & JPKL-CNTN5 & rs 2848479 & Intergenic & $\mathrm{A}$ & $3.29 * 10-10$ & 1.66 & Spanish & - & 26 \\
\hline
\end{tabular}

\section{HLA AND HLA-RELATED GENES ARE STRONGLY ASSOCIATED WITH BD}

\subsection{HLA}

Human Leucocyte Antigen (HLA) genes located on chromosome 6. HLA genes were among the most polymorphic genes in the human genome. To which several theories have been proposed to explain, including overdominance 
(heterozygote superiority) [13], negative frequency dependent selection (rare allele advantage) [14], and selection varying in time and space [15]. HLA genes were associated with susceptibility to almost all autoimmune diseases. Multiple HLA alleles have been associated with BD. Among them, HLA-B51 is considered the strongest genetic risk factor for BD, which has been verified in multiple studies and in different ethnic populations [16 - 26]. The population attributable risk (PAR) of HLA-B5/B51 was estimated to be 52.2\% for BD patients in Southern Europe, $49.9 \%$ in Middle East/North Africa, 44.4\% in East Asia, and 31.7\% in Northern Europe [27]. Other HLA alleles including BDrisk HLA-A02, -A24, -A26, -A31, -B27, -B57, and BD-protective HLA-A03, -B15, -B35, -B49, -B58 were also reported in different populations [26, 28 - 33].

In addition to susceptibility, HLA-A26:01 was also associated with poor visual prognosis in Japanese BD patients with uveitis [34], and with a high prevalence of posterior uveitis in Korean BD patients [35]. HLA-A26:01, -A02:07 and -A30:04 were associated with skin lesions and arthritis, uveitis, vascular lesions, genital ulcers, and a positive pathergy test in the Korean and Japanese populations [36].

These findings suggest that HLA alleles reflect clinical manifestations and prognosis, indicating the possibility of a clinical use as a biomarker for diagnostic or prognostic classification of BD patients.

\subsection{CIITA}

The class II major histocompatibility complex transactivator (CIITA) acts as a transcriptional coactivator that regulates the MHC class II genes, IL-4, IL-10 and other immune-mediating genes [37], which has been implicated in various inflammatory and autoimmune diseases [37, 38]. A recent study of a Chinese Han population indicated that CIITA SNP rs12932187 G allele and GG genotype were risk factors to BD, and the GG carriers had a higher expression of the CIITA gene and a lower level of IL-10 protein secretion from the peripheral blood monocytes (PBMC) in response to Lipopolysaccharide (LPS) stimulation [39].

\subsection{ERAP1}

Endoplasmic Reticulum Aminopeptidase 1 (ERAP1) functions to trim peptides in the endoplasmic reticulum to optimize their length for MHC-I binding. The SNPs rs10050860 and rs17482078 of the ERAP1 gene encoding p.Asp575Asn and Arg725Gln, respectively, were found to recessively confer risk to BD in Turkish population [40]. The ERAP-BD association was replicated in a Chinese cohort [41]. Further analysis of the Turkish and Spanish cohorts indicated that the peptidase variant ERAP1 p.Arg725Gln contributing to BD susceptibility may act through an interaction with the HLA-B*51 protein [40, 42]. Functional correlation studies indicated that the expression of ERAP1 in active BD patients was found significantly lower than that in healthy controls [41]. ERAP1 expression in AA carriers of SNP rs1065407 and CC carriers of SNP rs10050860 was higher than that observed in AC/CC carriers or CT/TT carriers by lipopolysaccharide (LPS)-stimulated peripheral blood mononuclear cell (PBMCs), respectively [41, 42].

\subsection{MICA}

The major histocompatibility complex class I chain related gene A (MICA) is a non-classic HLA gene [43]. It functions in immune activation under cellular stress conditions, such as infections, tissue injury, pro-inflammatory signals, and malignant transformation. Similar to classic HLA genes, its DNA sequence is highly polymorphic [44]. According to IMGT/HLA database [https:/www.ebi.ac.uk/ipd/imgt/hla/align.html], there are more than 100 identified MICA alleles. In addition, the codon 295 located in the Transmembrane (TM) region has a tri-nucleotide microsatellite polymorphism (GCT)n that is designated as An (A4, A5, A6, A9) allele, and a five repetition of GCT may coexist with a guanosine insertion that is designated as A5.1 [45].

The incidence of BD was strongly associated with MICA*009, *019 allele in a Spanish population [46], and MICAA6 allele in Japanese patients [47, 48]. The association between MICA-A6 and BD appeared to be independent from potential Linkage Disequilibrium (LD) effect of HLA-B51 in a Korean population study in which they examined the HLA-B51-negative BD patients [49].

On the other hand, MICA-A5.1 demonstrated a negative correlation with ocular lesions and iridocyclitis in BD patients [49, 50]. MICA-A9 was associated with BD patients who had less severe complications including uveitis, thrombosis, and neurological and intestinal involvement [51]. 


\section{MULTIPLE INTERLEUKINS (IL) FAMILY GENES ARE INVOLVED IN SUSCEPTIBILITY TO BD}

\subsection{IL-10}

IL-10 protein is an anti-inflammatory cytokine that inhibits the costimulatory activity of macrophages for $\mathrm{T}$ cell and NK cell activation and, production of proinflammatory cytokines such as IL-1, IL-6, IL-12, tumor necrosis factor (TNF), and interferon gamma (IFN- $\gamma$ ) [52, 53]. SNP rs 1800871 located at the IL-10 promoter region was first reported to be associated with BD in the UK or Middle Eastern (ME) cohorts [54]. The Genome-Wide Association Studies (GWAS) revealed multiple BD-associated SNPs (rs1518111, rs1554286, rs1800871 and rs1800872) of the IL-10 in a Chinese cohort [55] and Turkey, Japanese, Korean [56, 57].

\subsection{IL-12}

IL-12 is composed of a $35 \mathrm{kD}$ (IL-12p35 encoded by IL-12A) and a $40 \mathrm{kD}$ (IL-12p40 encoded by IL-12B) subunits. It binds to a heterodimeric IL-12 receptor (IL-12R) that consists of IL-12R $\beta 1$ (encoded by IL-12RB1and IL-12R $\beta 2$ (encoded by IL-12RB2) [58]. The IL-12A and the IL-12RB2 genes were linked to BD [37, 52, 53]. IL-12A encodes IL-12p35 that plays a crucial role in activation of NK cells and polarization of the Th1 pathway through differentiation from naïve CD4+ T cells [59], which produce IFN- $\gamma$, IL-2, TNF- $\beta$ and other cytokines [60]. A suggestive association of SNP rs1780546 of the IL-12A gene was reported in the Turkish and European BD cohorts [40, 61], and SNP rs17810458 was reported in an European BD cohort [61].

\subsection{IL-23R and IL-12RB2}

IL-23 is a member of the IL-12 family that share receptor and ligand chains with IL-12. However, it impacts on the development of Th17 cell responses that differs from IL-12 on Th1 [62]. The IL-23R and the IL-12RB1 genes encode for two subunits of the receptor for IL-23 [63] which are known to play a key role in neutrophil inflammation and in autoimmune diseases [64].

The GWAS identified the IL-23R SNP rs11209026 (Gly149Arg) in association with the Japanese cohort, and SNP rs76418789 (Arg381Gln) with the Turkish population [65]. In addition, the IL-23R/IL-12RB2 genes with multiple SNPs (rs1495965, rs924080 rs11209032, rs17375018, rs7517847, 10489629 and rs 1966176) were associated with BD in the cohorts of Turkey [56], Japanese [57], Han Chinese [66, 67], Iranian [68], Western Algeria [69] and Korean [70].

\section{GENES INVOLVED IN INFLAMMATION AND AUTOIMMUNITY ARE SIGNIFICANTLY ASSOCIATED WITH BD}

\subsection{MEFV}

The Mediterranean fever (MEFV) protein or pyrin is an important regulator of innate immunity and the inflammatory response to IL-1 $\beta$ and IFN- $\gamma$ [71]. MEFV SNPs rs61752717 (Met694Val), rs28940580(Met680Ile), rs3743930(Glu148Gln) have been linked to Familial Mediterranean fever [72] that share inflammatory nature and high prevalence in Middle Eastern and Mediterranean populations with BD. The MEFV gene polymorphisms Met694Val and Met680Ile were risk factors for BD and appeared consistent in multiple independent studies [65, 73 - 76]. In addition, specific BD risk polymorphisms (Met694Val, Met680Ile) of the MEFV gene were also associated with greater responsiveness to bacterial products $[74,75]$.

\subsection{IRF8}

Interferon Regulatory Factor (IRF) 8 is a transcription factor of the Interferon (IFN) Regulatory Factor (IRF) family that regulate expression of type I IFN stimulated genes, and play a vital role in regulating the development and function of a variety of immune cells [77]. Importantly, IRF8 can inhibit Th17 cell differentiation through its interaction with the Th17 master transcription factor, ROR- $\gamma$ t [78]. Two SNPs (rs17445836 and rs11642873) of the IRF8 gene were associated with BD in a Chinese cohort, and which appeared to regulate IRF8 expression and cytokine production [79]. Three other SNPs (rs11117433, rs142105922 and rs7203487) of the IRF8 gene were also associated with BD in the Turkish, Iranian and Japanese cohorts [80].

\subsection{TNFAIP3}

TNF- $\alpha$-induced protein 3 (TNFAIP3) is a ubiquitin-modifying enzyme A20 that regulates inflammation through 
NF- $\kappa$ B signaling pathway, and it can be induced by TNF, toll like receptors (TLRs), IL-1R, and NOD2 signaling [81 84]. A genetic association between the TNFAIP3 gene SNPs (rs9494885, rs10499194 and rs7753873) and BD was reported in Han Chinese [85], but not in the European population [86]. A Japanese study of familial BD indicated that a missense mutation C243Y in A20/TNFAIP3 was likely responsible for increased production of human inflammatory cytokines by reduced suppression of NF- $\kappa \mathrm{B}$ activation [87].

\subsection{REL}

The REL gene encodes for c-Rel, which is a member of the NF-kB family. Previous studies showed that Rel knockout mice do not develop autoimmune diseases [84, 85], which indicates its importance in the regulation of immune activity. The REL SNPs (rs842647) GG genotype and rs842647 G allele were reported to be risk factors to BD, and the latter was also associated with skin lesions in BD patients [88 - 90].

\subsection{TLR2,4}

Toll-Like Receptors (TLR) are transmembrane proteins that are implicated in pathogen recognition and activation of innate immunity [91]. The TLR2 SNP rs2289318 C allele and genotype CC and SNP rs3804099 CT genotype were significantly associated with ocular BD patients in a Chinese cohort. The TLR4 gene was associated with BD in multiple studies Japanese [92], Korea [93], Chinese [94] and Turkish populations, but not in Italian [95] and Tunisiam [96] cohorts. In addition, two BD protective TLR4 variants identified in Turkish cohort [70], p.Asp299Gly (rs4986790) and p.Thr399Ile (rs4986791) were associated with hyporesponsiveness to endotoxin [97].

\subsection{NOD1-NOD2}

Nucleotide-binding Oligomerization Domain (NOD) protein 1 and 2 are cytosolic protein that play important roles in initiating inflammation in response to microbial components such as those derived from bacterial peptidoglycan [98, 99]. Early studies suggested that Crohn's disease-associated Arg702Trp (rs2066844) of the NOD2 gene, was protective from BD [100]. Later, other independent studies using both targeted resequencing and next generation sequencing approaches supported NOD2 variants were significantly associated with BD [65, 101]. Recently, NOD1 was also reported as a BD-associated gene, in which minor allele (G) of NOD1 SNP rs2075818 was significantly decreased in the patients of a Chinese cohort [39].

\subsection{CCR1-CCR3}

CCR1 and CCR3 proteins are two C-C motif chemokine Receptor (CCR) family members, which are composed of 7-transmembrane structures. They couple to G- proteins for signal transduction within cells and serve as key regulators of leukocyte trafficking and immune system homeostasis [102]. The CCR1-CCR3 locus SNP rs7616215 was first found to be associated with BD in the Turkish GWAS [40]. A later study of Chinese population indicated a strong association of three SNPs (rs13084057, rs13092160 and rs13075270) of the CCR1-CCR3 with BD [103]. The association of the CCR1 gene was also verified in Turkish, Japanese and Iranian cohorts [40, 104]. Further studies of CCR1 mRNA expression in primary human monocytes indicated that CCR1 expression and monocyte chemotaxis were reduced in individuals carrying the BD-risk allele [40].

\subsection{GIMAP}

GTPase of the Immunity-Associated Protein (GIMAP) family are expressed most extensively in the immune system and are differentially regulated during early human Th cell differentiation, especially in the course of Th1 differentiation [105]. It is also involved in survival and apoptosis of T cells and some other cell types [105, 106]. An early GWAS suggested a GIMAP cluster including SNPs in GIMAP1 (rs2286900), GIMAP2 (rs10266069, rs10256482) and GIMAP4 (rs1916012, rs1522596 and rs1608157) is a susceptibility locus for BD in Korean and Japanese populations [107]. However, the association was not replicated in later study of European cohort [108].

\subsection{KLRC4}

Killer cell lectin-like receptor subfamily C, member 4 (KLRC4) is a member of NKG2 receptor family that regulate NK cell function. A suggestive association between SNPs of KLRC1-4 and BD was found in the GWAS of Turkish and Japanese cohorts [40]. It was then verified in Iranian cohort [104]. 


\section{GENES INVOLVED IN TRANSCRIPTION ACTIVATION OF IMMUNE REGULATION ARE ASSOCIATED WITH BD}

\subsection{STAT4}

Signal transducer and activator of transcription-4 (STAT4) is a transcription factor that activates gene expression involved in functional regulation and differentiation of T-helper cells, natural killer (NK) cells, mast cells and dendritic cells [109]. It modulates differentiation of naïve T cells into Th1 and Th17 cells $[60,110,111]$.

The association between the STAT4 gene and BD was first reported in a Han Chinese population [108]. It then was replicated in Korean, Turkish, Iranians [40, 104]. In addition, it was found that the risk allele A of STAT4 SNP rs897200 was associated with increased expression of the STAT4 gene, along with increased gene and protein expression of IL-17, which were correlated with a higher clinical severity score of BD patients [112].

\subsection{NCOA5}

Nuclear receptor coactivator-5 (NCOA5) protein regulates nuclear receptor subfamily 1 group D member 2 (NR1D2) and estrogen receptor 1 and 2 (ESR1 and ESR2) [113, 114]. NCOA5 SNP rs2903908 was associated with BD in the Finlang and the Turkish cohorts, and the CT genotype of rs 2903908 was associated with genital ulceration and uveitis of the BD patients [115].

\subsection{FOXP3}

FOXP3 (forkhead box P3), also known as scurfin, is an important transcription factor regulating the development and function of Treg cells $[116,117]$. The SNP rs3761548 (3279 C/A) of the FOXP3 gene was significantly associated with BD in the North-Western Iranian population [118]. Another study showed that a low Copy Number Variant (CNV) of the FOXP3 gene conferred a risk to female BD patients, not male in a Chinese cohort [119].

\section{OTHER GENES}

\subsection{PSORS1C1}

Psoriasis susceptibility 1 candidate 1 (PSORS1C1) gene was initially recognized as it confers susceptibility to psoriasis [120] and psoriatic arthritis [121]. Recently, it was found to be a shared genetic factor in several other rheumatic diseases such as scleroderma [122], Crohn's disease [123] and BD (SNP rs12525170) [124]. Although the function remains unclear, it is believed that PSORS1C1 contributes to the pathogenesis of autoimmunity $[125,126]$.

\subsection{FUT2}

The FUT2 gene encodes fucosyltransferase 2, which is involved in synthesis of the $\mathrm{H}$ antigen, the precursor of the ABO-histo-blood group antigen in body fluids and on the intestinal mucosa [127]. The association of FUT2 SNPs (rs632111, rs601338, rs602662, rs492602, rs681343 and rs281377) with BD was found in Iranian and Turkish population [128].

\subsection{UBAC2}

Ubiquitin-associated domain containing 2 (UBAC2) protein may be involved in protein localization in the endoplasmic reticulum [129]. Association of the UBAC2 gene with BD was first found in Turkish (SNP rs9513584) [130]. Additional BD-associated UBAC2 SNPs (rs7999348, rs9517723, rs3825427, rs9517668 and rs9517701) were found in Chinese, Italian and Japanese populations [131 - 133]. Moreover, the presence of BD-risk alleles of the rs9517723 was correlated with an increased expression of the UBAC2 gene which could induce over-activation of ubiquitination-related pathway leading to the development of ocular and CNS lesions in BD [133].

\subsection{SUMO4}

Small Ubiquitin-like Modifier 4 (SUMO4) is a member of the SUMO family that post-transcriptionally sumoylate proteins to regulate subcellular localization and/or enhance protein stability and activity [134]. It negatively regulated $\mathrm{NF} \kappa \mathrm{B}$ activity indicating its role in immune regulation [135]. The genetic association between the SUMO4 (SNPs rs237024, rs237026) and BD was first reported in a Chinese cohort, and that appeared independent from HLA-B51 [136]. The association was replicated in Tunisian and Korean cohorts [137,138], and specific polymorphisms were also 
associated with disease severity, skin lesions and vascular involvement of BD patients [137,138].

\subsection{Loci at ADO-EGR2, CEBPB-PTPN1, JRKL-CNTN5}

In addition to above genes, two genetic loci between the ADO and the EGR2 genes, and the CEBPB and the PTPN1 genes were associated with BD in a study of profiling immune-related loci in the Turkish, Iranian and Japanese cohorts [80]. The ADO encodes cysteamine (2-aminoethanethiol) dioxygenase that is involved in amino acid metabolism [139]. The EGR2 encodes early growth response protein 2 that is a transcription regulatory factor, and highly expressed in a population of migrating neural crest cells [140]. CEBPB encodes CCAAT/Enhancer Binding Protein Beta, a member of the CCAAT/enhancer binding protein family of basic leucine zipper transcription factors. It plays an important roles in controlling cell differentiation and proliferation, as well as in inflammation [141]. The PTPN1 gene encodes protein tyrosine phosphatase, non-receptor type 1 that functions as a key regulator of immune homeostasis by inhibiting T-cell receptor signaling and by selectively promoting type I interferon responses after activation of myeloid-cell patternrecognition receptors [142]. Moreover, the locus between JRKL and CNTN5 also was significantly associated with BD in a study of Spanish population [26]. It is worth noting that these BD-linked loci do not directly reflect the association of the genes, but may be suggestive for further investigation.

\section{CONCLUSION}

Multiple genes have been associated with BD, and they are largely involved in immune activation and regulation. The multigenic feature of BD underlies complex pathogenesis. Some of the reported associations appeared to be conflict in different study cohorts and populations, which suggests the BD-associated polymorphisms of the genes may be ethnic specific, and further verification may be warranted. In addition, some of the BD-associated genes, especially immune regulatory genes, have also been reported in other rheumatic diseases, which supports the shared genetic effects among immune-mediated diseases. Moreover, specific gene polymorphisms were associated with clinical presentation of BD such as ocular lesions, neurological and intestinal involvement. Although functional significance of the BD-associated gene polymorphisms has not been well-defined, understanding the genetics of BD will provide insights into pathogenesis of the disease and an opportunity to interrogate candidate genes in potential diagnostic and therapeutic applications.

\section{CONSENT FOR PUBLICATION}

Not applicable.

\section{CONFLICT OF INTEREST}

The authors declare no conflict of interest, financial or otherwise.

\section{ACKNOWLEDGEMENTS}

Declared none.

\section{REFERENCES}

[1] Saadoun D, Wechsler B. Behçet's disease. Orphanet J Rare Dis 2012; 12: 7-20. [http://dx.doi.org/10.1186/1750-1172-7-20]

[2] Verity DH, Marr JE, Ohno S, Wallace GR, Stanford MR. Behçet's disease, the silk road and HLA-B51: Historical and geographical perspectives. Tissue Antigens 1999; 54(3): 213-20. [http://dx.doi.org/10.1034/j.1399-0039.1999.540301.x] [PMID: 10519357]

[3] Calamia KT, Wilson FC, Icen M, Crowson CS, Gabriel SE, Kremers HM. HLA and non-HLA genes in Behçet's disease: A multicentric study in the Spanish population: A population-based study. Arthritis Rheum 2009; 61: 600-4. [http://dx.doi.org/10.1002/art.24423] [PMID: 19405011]

[4] Shahram F, Jamshidi AR, Hirbod-Mobarakeh A, Habibi G, Mardani A, Ghaemi M. Scientometric analysis and mapping of scientific articles on Behcet's disease. Int J Rheum Dis 2013; 16(2): 185-92. [http://dx.doi.org/10.1111/1756-185X.12087] [PMID: 23773643]

[5] Azizlerli G, Köse AA, Sarica R, et al. Prevalence of Behçet's disease in Istanbul, Turkey. Int J Dermatol 2003; 42 (10): 803-6. [http://dx.doi.org/10.1046/j.1365-4362.2003.01893.x] [PMID: 14521694]

[6] Yurdakul S, Günaydin I, Tüzün Y, et al. The prevalence of Behçet's syndrome in a rural area in northern Turkey. J Rheumatol 1988; 15(5): 820-2. [PMID: 3172095] 
[7] Idil A, Gürler A, Boyvat A, et al. The prevalence of Behçet's disease above the age of 10 years. The results of a pilot study conducted at the Park Primary Health Care Center in Ankara, Turkey. Ophthalmic Epidemiol 2002; 9(5): 325-31. [http://dx.doi.org/10.1076/opep.9.5.325.10338] [PMID: 12528917]

[8] Shahram F, Davatchi F, Nadji A, et al. Recent epidemiological data on Behçet's disease in Iran. The 2001 survey. Adv Exp Med Biol 2003; 528: 31-6. [http://dx.doi.org/10.1007/0-306-48382-3_5] [PMID: 12918656]

[9] Ohno S, Aoki K, Sugiura S, Nakayama E, Itakura K, Aizawa M. Letter: HL-A5 and Behçet’s disease. Lancet 1973; 2(7842): 1383-4. [http://dx.doi.org/10.1016/S0140-6736(73)93343-6] [PMID: 4128069]

[10] Ohno S, Ohguchi M, Hirose S, Matsuda H, Wakisaka A, Aizawa M. Close association of HLA-Bw51 with Behçet's disease. Arch Ophthalmol 1982; 100(9): 1455-8.

[http://dx.doi.org/10.1001/archopht.1982.01030040433013] [PMID: 6956266]

[11] Saadoun D, Wechsler B, Desseaux K, et al. Mortality in Behçet's disease. Arthritis Rheum 2010; 62(9): $2806-12$. [http://dx.doi.org/10.1002/art.27568] [PMID: 20496419]

[12] Demirseren DD, Ceylan GG, Akoglu G, et al. HLA-B51 subtypes in Turkish patients with Behçet's disease and their correlation with clinical manifestations. Genet Mol Res 2014; 13(3): 4788-96. [http://dx.doi.org/10.4238/2014.July.2.8] [PMID: 25062414]

[13] Hamzaoui A, Houman MH, Massouadia M, et al. Contribution of Hla-B51 in the susceptibility and specific clinical features of Behcet's disease in Tunisian patients. Eur J Intern Med 2012; 23(4): 347-9. [http://dx.doi.org/10.1016/j.ejim.2011.12.011] [PMID: 22560383]

[14] Salvarani C, Boiardi L, Mantovani V, et al. Association of MICA alleles and HLA-B51 in Italian patients with Behçet's disease. J Rheumatol 2001; 28(8): 1867-70. [PMID: 11508592]

[15] Kilmartin DJ, Finch A, Acheson RW. Primary association of HLA-B51 with Behçet's disease in Ireland. Br J Ophthalmol 1997; 81(8): 649-53.

[http://dx.doi.org/10.1136/bjo.81.8.649] [PMID: 9349151]

[16] Lennikov A, Alekberova Z, Goloeva R, et al. Single center study on ethnic and clinical features of Behcet's disease in Moscow, Russia. Clin Rheumatol 2015; 34(2): 321-7. [http://dx.doi.org/10.1007/s10067-013-2442-9] [PMID: 24322831]

[17] Paul M, Klein T, Krause I, Molad Y, Narinsky R, Weinberger A. Allelic distribution of HLA-B*5 in HLA-B5-positive Israeli patients with Behçet's disease. Tissue Antigens 2001; 58(3): 185-6. [http://dx.doi.org/10.1034/j.1399-0039.2001.580307.x] [PMID: 11703827]

[18] Mizuki N, Ota M, Katsuyama Y, et al. Sequencing-based typing of HLA-B*51 alleles and the significant association of HLA-B*5101 and B*5108 with Behçet's disease in Greek patients. Tissue Antigens 2002; 59(2): 118-21. [http://dx.doi.org/10.1034/j.1399-0039.2002.590207.x] [PMID: 12028538]

[19] Koumantaki Y, Stavropoulos C, Spyropoulou M, et al. HLA-B*5101 in Greek patients with Behçet's disease. Hum Immunol 1998; 59(4): 250-5. [http://dx.doi.org/10.1016/S0198-8859(98)00011-1] [PMID: 9568801]

[20] Mizuki N, Ota M, Katsuyama Y, et al. HLA class I genotyping including HLA-B*51 allele typing in the Iranian patients with Behçet's disease. Tissue Antigens 2001; 57(5): 457-62.

[http://dx.doi.org/10.1034/j.1399-0039.2001.057005457.x] [PMID: 11556970]

[21] Ortiz-Fernández L, Carmona FD, Montes-Cano MA, et al. Genetic analysis with the immunochip platform in behçet disease. Identification of residues associated in the HLA class I region and new susceptibility loci. PLoS One 2016; 11(8): e 0161305. [http://dx.doi.org/10.1371/journal.pone.0161305] [PMID: 27548383]

[22] de Menthon M, Lavalley MP, Maldini C, Guillevin L, Mahr A. HLA-B51/B5 and the risk of Behçet's disease: A systematic review and metaanalysis of case-control genetic association studies. Arthritis Rheum 2009; 61(10): 1287-96. [http://dx.doi.org/10.1002/art.24642] [PMID: 19790126]

[23] Montes-Cano MA, Conde-Jaldón M, García-Lozano JR, et al. HLA and non-HLA genes in Behçet's disease: A multicentric study in the Spanish population. Arthritis Res Ther 2013; 15(5): R145. [http://dx.doi.org/10.1186/ar4328] [PMID: 24286189]

[24] Takeuchi M, Kastner DL, Remmers EF. The immunogenetics of Behçet's disease: A comprehensive review. J Autoimmun 2015; 64: 137-48. [http://dx.doi.org/10.1016/j.jaut.2015.08.013] [PMID: 26347074]

[25] Radouane A, Oudghiri M, Chakib A, et al. HLA-B*27 allele associated to Behçet's disease and to anterior uveitis in Moroccan patients. Ann Biol Clin (Paris) 2011; 69(4): 419-24. [PMID: 21896406]

[26] Giza M, Koftori D, Chen L, Bowness P. Is Behçet's disease a 'class 1-opathy'? The role of HLA-B*51 in the pathogenesis of Behçet's disease. Clin Exp Immunol 2018; 191(1): 11-8. [http://dx.doi.org/10.1111/cei.13049] [PMID: 28898393] 
[27] Meguro A, Inoko H, Ota M, et al. Genetics of behçet disease inside and outside the MHC. Ann Rheum Dis 2010; 69(4): 747-54. [http://dx.doi.org/10.1136/ard.2009.108571] [PMID: 19684014]

[28] Al-Okaily F, Al-Rashidi S, Al-Balawi M, Mustafa M, Arfin M, Al-Asmari A. Genetic association of HLA-A*26, -A*31, and -B*51 with behcet's disease in saudi patients. Clin Med Insights Arthritis Musculoskelet Disord 2016; 9: 167-73. [http://dx.doi.org/10.4137/CMAMD.S39879] [PMID: 27547040]

[29] Hughes T, Coit P, Adler A, et al. Identification of multiple independent susceptibility loci in the HLA region in Behçet's disease. Nat Genet 2013; 45(3): 319-24. [http://dx.doi.org/10.1038/ng.2551] [PMID: 23396137]

[30] Kaburaki T, Takamoto M, Numaga J, et al. Genetic association of HLA-A*2601 with ocular Behçet's disease in Japanese patients. Clin Exp Rheumatol 2010; 28(4)(Suppl. 60): S39-44. [PMID: 20868569]

[31] Kang EH, Park JW, Park C, et al. Genetic and non-genetic factors affecting the visual outcome of ocular Behcet's disease. Hum Immunol 2013; 74(10): 1363-7. [http://dx.doi.org/10.1016/j.humimm.2013.06.036] [PMID: 23831258]

[32] Kang EH, Kim JY, Takeuchi F, et al. Associations between the HLA-A polymorphism and the clinical manifestations of Behcet's disease. Arthritis Res Ther 2011; 13(2): R49. [http://dx.doi.org/10.1186/ar3292] [PMID: 21429233]

[33] Ting JP, Trowsdale J. Genetic control of MHC class II expression. Cell 2002; 109(Suppl.): S21-33. [http://dx.doi.org/10.1016/S0092-8674(02)00696-7] [PMID: 11983150]

[34] Devaiah BN, Singer DS. CIITA and its dual roles in MHC gene transcription. Front Immunol 2013; 4: 476-81. [http://dx.doi.org/10.3389/fimmu.2013.00476] [PMID: 24391648]

[35] Li L, Yu H, Jiang Y, et al. Genetic variations of NLR family genes in behcet's disease. Sci Rep 2016; 6: $20098-104$. [http://dx.doi.org/10.1038/srep20098] [PMID: 26833430]

[36] Kirino Y, Bertsias G, Ishigatsubo Y, et al. Genome-wide association analysis identifies new susceptibility loci for Behçet's disease and epistasis between HLA-B*51 and ERAP1. Nat Genet 2013; 45(2): 202-7. [http://dx.doi.org/10.1038/ng.2520] [PMID: 23291587]

[37] Zhang L, Yu H, Zheng M, et al. Association of ERAP1 gene polymorphisms with behçet's disease in han chinese. Invest Ophthalmol Vis Sci 2015; 56(10): 6029-35. [http://dx.doi.org/10.1167/iovs.15-17544] [PMID: 26393469]

[38] Conde-Jaldón M, Montes-Cano MA, García-Lozano JR, et al. Epistatic interaction of ERAP1 and HLA-B in behçet disease: A replication study in the Spanish population. PLoS One 2014; 9(7): e102100. [http://dx.doi.org/10.1371/journal.pone.0102100] [PMID: 25019531]

[39] Bahram S, Bresnahan M, Geraghty DE, Spies T. A second lineage of mammalian major histocompatibility complex class I genes. Proc Natl Acad Sci USA 1994; 91(14): 6259-63. [http://dx.doi.org/10.1073/pnas.91.14.6259] [PMID: 8022771]

[40] Choy MK, Phipps ME. MICA polymorphism: Biology and importance in immunity and disease. Trends Mol Med 2010; 16(3): 97-106. [http://dx.doi.org/10.1016/j.molmed.2010.01.002] [PMID: 20153697]

[41] Zhou X, Wang J, Zou H, et al. MICA, a gene contributing strong susceptibility to ankylosing spondylitis. Ann Rheum Dis 2014; 73(8): $1552-7$ [http://dx.doi.org/10.1136/annrheumdis-2013-203352] [PMID: 23727634]

[42] Muñoz-Saá I, Cambra A, Pallarés L, et al. Allelic diversity and affinity variants of MICA are imbalanced in Spanish patients with Behçet's disease. Scand J Immunol 2006; 64(1): 77-82. [http://dx.doi.org/10.1111/j.1365-3083.2006.01780.x] [PMID: 16784494]

[43] Mizuki N, Ota M, Kimura M, et al. Triplet repeat polymorphism in the transmembrane region of the MICA gene: a strong association of six GCT repetitions with Behçet disease. Proc Natl Acad Sci USA 1997; 94(4): 1298-303. [http://dx.doi.org/10.1073/pnas.94.4.1298] [PMID: 9037047]

[44] Wei F, Zhang YU, Li W. A meta-analysis of the association between Behçet's disease and MICA-A6. Biomed Rep 2016; 4(6): 741-5. [http://dx.doi.org/10.3892/br.2016.644] [PMID: 27284416]

[45] Park SH, Park KS, Seo YI, et al. Association of MICA polymorphism with HLA-B51 and disease severity in Korean patients with Behcet's disease. J Korean Med Sci 2002; 17(3): 366-70. [http://dx.doi.org/10.3346/jkms.2002.17.3.366] [PMID: 12068141]

[46] Zhang J, Liao D, Yang L, Hou S. Association between functional MICA-TM and behcet's disease: A systematic review and meta-analysis. Sci Rep 2016; 6: 21033 [http://dx.doi.org/10.1038/srep21033] [PMID: 26875668]

[47] Nishiyama M, Takahashi M, Manaka KC, Roosihermiatie B, Kuriyama T, Nakae K. Research report: Frequencies of mica gene polymorphism: A comparison between Indonesians on Bacan Island and suburban Japanese. Southeast Asian J Trop Med Public Health 2004; 35(1): 195-201. 
[PMID: 15272769]

[48] Fiorentino DF, Zlotnik A, Vieira P, et al. IL-10 acts on the antigen-presenting cell to inhibit cytokine production by Th1 cells. J Immunol 1991; 146(10): 3444-51. [PMID: 1827484]

[49] Mosmann TR, Coffman RL. TH1 and TH2 cells: Different patterns of lymphokine secretion lead to different functional properties. Annu Rev Immunol 1989; 7: 145-73.

[http://dx.doi.org/10.1146/annurev.iy.07.040189.001045] [PMID: 2523712]

[50] Wallace GR, Kondeatis E, Vaughan RW, et al. IL-10 genotype analysis in patients with Behçet's disease. Hum Immunol 2007; 68(2): $122-7$. [http://dx.doi.org/10.1016/j.humimm.2006.11.010] [PMID: 17321902]

[51] Hu J, Hou S, Zhu X, et al. Interleukin-10 gene polymorphisms are associated with Behcet's disease but not with Vogt-Koyanagi-Harada syndrome in the Chinese Han population. Mol Vis 2015; 21: 589-603. [PMID: 26015771]

[52] Remmers EF, Cosan F, Kirino Y, et al. Genome-wide association study identifies variants in the MHC class I, IL10, and IL23R-IL12RB2 regions associated with Behçet's disease. Nat Genet 2010; 42(8): 698-702. [http://dx.doi.org/10.1038/ng.625] [PMID: 20622878]

[53] Mizuki N, Meguro A, Ota M, et al. Genome-wide association studies identify IL23R-IL12RB2 and IL10 as Behçet's disease susceptibility loci. Nat Genet 2010; 42(8): 703-6.

[http://dx.doi.org/10.1038/ng.624] [PMID: 20622879]

[54] Akdis M, Burgler S, Crameri R, et al. Interleukins, from 1 to 37, and interferon- $\gamma$ : receptors, functions, and roles in diseases. J Allergy Clin Immunol 2011; 127(3): 701-21.e1, 70. [http://dx.doi.org/10.1016/j.jaci.2010.11.050] [PMID: 21377040]

[55] Chang JT, Shevach EM, Segal BM. Regulation of interleukin (IL)-12 receptor beta2 subunit expression by endogenous IL-12: a critical step in the differentiation of pathogenic autoreactive T cells. J Exp Med 1999; 189(6): 969-78.

[http://dx.doi.org/10.1084/jem.189.6.969] [PMID: 10075980]

[56] Watford WT, Hissong BD, Bream JH, Kanno Y, Muul L, O'Shea JJ. Signaling by IL-12 and IL-23 and the immunoregulatory roles of STAT4. Immunol Rev 2004; 202: 139-56.

[http://dx.doi.org/10.1111/j.0105-2896.2004.00211.x] [PMID: 15546391]

[57] Kappen JH, Medina-Gomez C, van Hagen PM, et al. Genome-wide association study in an admixed case series reveals IL12A as a new candidate in Behçet disease. PLoS One 2015; 10(3): e0119085. [http://dx.doi.org/10.1371/journal.pone.0119085] [PMID: 25799145]

[58] Murphy CA, Langrish CL, Chen Y, et al. Divergent pro- and antiinflammatory roles for IL-23 and IL-12 in joint autoimmune inflammation. J Exp Med 2003; 198(12): 1951-7.

[http://dx.doi.org/10.1084/jem.20030896] [PMID: 14662908]

[59] Iwakura Y, Ishigame H. The IL-23/IL-17 axis in inflammation. J Clin Invest 2006; 116(5): 1218-22. [http://dx.doi.org/10.1172/JCI28508] [PMID: 16670765]

[60] Steinman L. Mixed results with modulation of TH-17 cells in human autoimmune diseases. Nat Immunol 2010; 11(1): 41-4. [http://dx.doi.org/10.1038/ni.1803] [PMID: 20016509]

[61] Yu H, Zheng M, Zhang L, et al. Identification of susceptibility SNPs in IL10 and IL23R-IL12RB2 for Behçet's disease in Han Chinese. J Allergy Clin Immunol 2017; 139(2): 621-7.

[http://dx.doi.org/10.1016/j.jaci.2016.05.024] [PMID: 27464962]

[62] Qin X, Xu J, Wu Z, et al. Association study of rs924080 and rs11209032 polymorphisms of IL23R-IL12RB2 in a Northern Chinese Han population with Behcet's disease. Hum Immunol 2016; 77(12): 1284-90. [http://dx.doi.org/10.1016/j.humimm.2016.09.006] [PMID: 27660093]

[63] Xavier JM, Shahram F, Davatchi F, et al. Association study of IL10 and IL23R-IL12RB2 in Iranian patients with Behçet's disease. Arthritis Rheum 2012; 64(8): 2761-72. [http://dx.doi.org/10.1002/art.34437] [PMID: 22378604]

[64] Khaib Dit Naib O, Aribi M, Idder A, et al. Association Analysis of IL10, TNF- $\alpha$, and IL23R-IL12RB2 SNPs with Behçet's Disease Risk in Western Algeria. Front Immunol 2013; 4: 342.

[http://dx.doi.org/10.3389/fimmu.2013.00342] [PMID: 24151497]

[65] Kang EH, Kim S, Park MY, et al. Behçet's disease risk association fine-mapped on the IL23R-IL12RB2 intergenic region in Koreans. Arthritis Res Ther 2017; 19(1): 227. [http://dx.doi.org/10.1186/s13075-017-1435-5] [PMID: 29017598]

[66] Chae JJ, Wood G, Masters SL, et al. The B30.2 domain of pyrin, the familial Mediterranean fever protein, interacts directly with caspase-1 to modulate IL-1beta production. Proc Natl Acad Sci USA 2006; 103(26): 9982-7. [http://dx.doi.org/10.1073/pnas.0602081103] [PMID: 16785446]

[67] French FMF. A candidate gene for familial Mediterranean fever. Nat Genet 1997; 17(1): 25-31. [http://dx.doi.org/10.1038/ng0997-25] [PMID: 9288094] 
[68] Touitou I, Magne X, Molinari N, et al. MEFV mutations in Behçet's disease. Hum Mutat 2000; 16(3): $271-2$. [http://dx.doi.org/10.1002/1098-1004(200009)16:3<271::AID-HUMU16>3.0.CO;2-A] [PMID: 10980540]

[69] Esmaeili M, Bonyadi M, Khabbazi A, et al. Common MEFV mutations in iranian azeri turkish patients with behçet's disease. Scand J Rheumatol 2011; 40(5): 383-6.

[http://dx.doi.org/10.3109/03009742.2011.562532] [PMID: 21623663]

[70] Kirino Y, Zhou Q, Ishigatsubo Y, et al. Targeted resequencing implicates the familial Mediterranean fever gene MEFV and the toll-like receptor 4 gene TLR4 in Behçet disease. Proc Natl Acad Sci USA 2013; 110(20): 8134-9. [http://dx.doi.org/10.1073/pnas.1306352110] [PMID: 23633568]

[71] Wu Z, Zhang S, Li J, et al. Association between MEFV mutations M694V and M680I and behçet's disease: A meta-analysis. PLoS One 2015; 10(7): e0132704.

[http://dx.doi.org/10.1371/journal.pone.0132704] [PMID: 26176758]

[72] Tasliyurt T, Yigit S, Rustemoglu A, Gul U, Ates O. Common MEFV gene mutations in Turkish patients with Behcet's disease. Gene 2013; 530(1): 100-3.

[http://dx.doi.org/10.1016/j.gene.2013.08.026] [PMID: 23973724]

[73] Holtschke T, Löhler J, Kanno Y, et al. Immunodeficiency and chronic myelogenous leukemia-like syndrome in mice with a targeted mutation of the ICSBP gene. Cell 1996; 87(2): 307-17. [http://dx.doi.org/10.1016/S0092-8674(00)81348-3] [PMID: 8861914]

[74] Ouyang X, Zhang R, Yang J, et al. Transcription factor IRF8 directs a silencing programme for TH17 cell differentiation. Nat Commun 2011; 2: 314 .

[http://dx.doi.org/10.1038/ncomms1311] [PMID: 21587231]

[75] Jiang Y, Wang H, Yu H, et al. Two genetic variations in the IRF8 region are associated with behçet's disease in han chinese. Sci Rep 2016; 6: 19651. [http://dx.doi.org/10.1038/srep19651] [PMID: 26794091]

[76] Takeuchi M, Mizuki N, Meguro A, et al. Dense genotyping of immune-related loci implicates host responses to microbial exposure in Behçet's disease susceptibility. Nat Genet 2017; 49(3): 438-43. [http://dx.doi.org/10.1038/ng.3786] [PMID: 28166214]

[77] Boone DL, Turer EE, Lee EG, et al. The ubiquitin-modifying enzyme A20 is required for termination of Toll-like receptor responses. Nat Immunol 2004; 5(10): 1052-60.

[http://dx.doi.org/10.1038/ni1110] [PMID: 15334086]

[78] Hitotsumatsu O, Ahmad RC, Tavares R, et al. The ubiquitin-editing enzyme A20 restricts nucleotide-binding oligomerization domain containing 2-triggered signals. Immunity 2008; 28(3): 381-90. [http://dx.doi.org/10.1016/j.immuni.2008.02.002] [PMID: 18342009]

[79] Jäättelä M, Mouritzen H, Elling F, Bastholm L. A20 zinc finger protein inhibits TNF and IL-1 signaling. J Immunol 1996; $156(3)$ : 1166-73. [PMID: 8557994]

[80] Lee EG, Boone DL, Chai S, et al. Failure to regulate TNF-induced NF-kappaB and cell death responses in A20-deficient mice. Science 2000; 289(5488): 2350-4. [http://dx.doi.org/10.1126/science.289.5488.2350] [PMID: 11009421]

[81] Li H, Liu Q, Hou S, et al. TNFAIP3 gene polymorphisms confer risk for behcet's disease in a chinese han population. Hum Genet 2013; 132(3): 293-300.

[http://dx.doi.org/10.1007/s00439-012-1250-7] [PMID: 23161053]

[82] Ortiz-Fernández L, García-Lozano JR, Montes-Cano MA, et al. Lack of association of TNFAIP3 and JAK1 with Behçet's disease in the European population. Clin Exp Rheumatol 2015; 33(6)(Suppl. 94): S36-9. [PMID: 26005883]

[83] Shigemura T, Kaneko N, Kobayashi N, et al. Novel heterozygous C243Y A20/TNFAIP3 gene mutation is responsible for chronic inflammation in autosomal-dominant Behçet's disease. RMD Open 2016; 2(1): e000223. [http://dx.doi.org/10.1136/rmdopen-2015-000223] [PMID: 27175295]

[84] Chen G, Hardy K, Pagler E, et al. The NF- $\kappa \mathrm{B}$ transcription factor c-Rel is required for Th17 effector cell development in experimental autoimmune encephalomyelitis. J Immunol 2011; 187(9): 4483-91. [http://dx.doi.org/10.4049/jimmunol.1101757] [PMID: 21940679]

[85] Lamhamedi-Cherradi SE, Zheng S, Hilliard BA, et al. Transcriptional regulation of type I diabetes by NF-kappa B. J Immunol 2003; 171(9): 4886-92. [http://dx.doi.org/10.4049/jimmunol.171.9.4886] [PMID: 14568969]

[86] Chen F, Xu L, Zhao T, Xiao X, Pan Y, Hou S. Genetic variation in the REL gene increases risk of behcet's disease in a chinese han population but That of PRKCQ does not. PLoS One 2016; 11(1): e0147350. [http://dx.doi.org/10.1371/journal.pone.0147350] [PMID: 26784953]

[87] Poltorak A, He X, Smirnova I, et al. Defective LPS signaling in C3H/HeJ and C57BL/10ScCr mice: Mutations in Tlr4 gene. Science 1998; 282(5396): 2085-8. 
[http://dx.doi.org/10.1126/science.282.5396.2085] [PMID: 9851930]

[88] Meguro A, Ota M, Katsuyama Y, et al. Association of the toll-like receptor 4 gene polymorphisms with Behcet's disease. Ann Rheum Dis 2008; 67(5): 725-7.

[http://dx.doi.org/10.1136/ard.2007.079871] [PMID: 18408113]

[89] Horie Y, Meguro A, Ota M, et al. Association of TLR4 polymorphisms with Behcet's disease in a Korean population. Rheumatology (Oxford) 2009; 48(6): 638-42.

[http://dx.doi.org/10.1093/rheumatology/kep077] [PMID: 19395541]

[90] Fang J, Hu R, Hou S, et al. Association of TLR2 gene polymorphisms with ocular behcet's disease in a Chinese han population. Invest Ophthalmol Vis Sci 2013; 54(13): 8384-92. [http://dx.doi.org/10.1167/iovs.13-12878] [PMID: 24255044]

[91] Boiardi L, Atzeni F, Casali B, et al. Toll-like receptor 4 (TLR4) gene polymorphisms in Italian patients with Behçet's disease. Clin Exp Rheumatol 2009; 27(2)(Suppl. 53): S43-7.

[PMID: 19796532]

[92] Ben Dhifallah I, Lachheb J, Houman H, Hamzaoui K. Toll-like-receptor gene polymorphisms in a Tunisian population with Behçet’s disease. Clin Exp Rheumatol 2009; 27(2)(Suppl. 53): S58-62. [PMID: 19796535]

[93] Arbour NC, Lorenz E, Schutte BC, et al. TLR4 mutations are associated with endotoxin hyporesponsiveness in humans. Nat Genet 2000; 25(2): 187-91. [http://dx.doi.org/10.1038/76048] [PMID: 10835634]

[94] Strober W, Murray PJ, Kitani A, Watanabe T. Signalling pathways and molecular interactions of NOD1 and NOD2. Nat Rev Immunol 2006; 6(1): 9-20.

[http://dx.doi.org/10.1038/nri1747] [PMID: 16493424]

[95] Moreira LO, Zamboni DS. NOD1 and NOD2 signaling in infection and inflammation. Front Immunol 2012; 3: $328-34$. [http://dx.doi.org/10.3389/fimmu.2012.00328] [PMID: 23162548]

[96] Kappen JH, Wallace GR, Stolk L, et al. Low prevalence of NOD2 SNPs in Behçet's disease suggests protective association in Caucasians. Rheumatology (Oxford) 2009; 48(11): 1375-7. [http://dx.doi.org/10.1093/rheumatology/kep292] [PMID: 19748964]

[97] Burillo-Sanz S, Montes-Cano MA, García-Lozano JR, et al. Mutational profile of rare variants in inflammasome-related genes in Behçet disease: A Next Generation Sequencing approach. Sci Rep 2017; 7(1): 8453. [http://dx.doi.org/10.1038/s41598-017-09164-7] [PMID: 28814775]

[98] Di Marzio P, Dai WW, Franchin G, Chan AY, Symons M, Sherry B. Role of Rho family GTPases in CCR1- and CCR5-induced actin reorganization in macrophages. Biochem Biophys Res Commun 2005; 331(4): 909-16.

[http://dx.doi.org/10.1016/j.bbrc.2005.04.015] [PMID: 15882964]

[99] Hou S, Xiao X, Li F, Jiang Z, Kijlstra A, Yang P. Two-stage association study in Chinese Han identifies two independent associations in CCR1/CCR3 locus as candidate for Behçet's disease susceptibility. Hum Genet 2012; 131(12): 1841-50. [http://dx.doi.org/10.1007/s00439-012-1200-4] [PMID: 22829007]

[100] Sousa I, Shahram F, Francisco D, et al. Brief report: association of CCR1, KLRC4, IL12A-AS1, STAT4, and ERAP1 With Behçet's disease in Iranians. Arthritis Rheumatol 2015; 67(10): 2742-8. [http://dx.doi.org/10.1002/art.39240] [PMID: 26097239]

[101] Filén JJ, Filén S, Moulder R, et al. Quantitative proteomics reveals GIMAP family proteins 1 and 4 to be differentially regulated during human T helper cell differentiation. Mol Cell Proteomics 2009; 8(1): 32-44. [http://dx.doi.org/10.1074/mcp.M800139-MCP200] [PMID: 18701445]

[102] Saunders A, Webb LM, Janas ML, et al. Putative GTPase GIMAP1 is critical for the development of mature B and T lymphocytes. Blood 2010; 115(16): 3249-57. [http://dx.doi.org/10.1182/blood-2009-08-237586] [PMID: 20194894]

[103] Lee YJ, Horie Y, Wallace GR, et al. Genome-wide association study identifies GIMAP as a novel susceptibility locus for Behcet's disease. Ann Rheum Dis 2013; 72(9): 1510-6.

[http://dx.doi.org/10.1136/annrheumdis-2011-200288] [PMID: 23041938]

[104] Ortiz-Fernández L, Conde-Jaldón M, García-Lozano JR, et al. GIMAP and Behçet disease: no association in the European population. Ann Rheum Dis 2014; 73(7): 1433-4.

[http://dx.doi.org/10.1136/annrheumdis-2013-205156] [PMID: 24625627]

[105] Morinobu A, Gadina M, Strober W, et al. STAT4 serine phosphorylation is critical for IL-12-induced IFN-gamma production but not for cell proliferation. Proc Natl Acad Sci USA 2002; 99(19): 12281-6. [http://dx.doi.org/10.1073/pnas.182618999] [PMID: 12213961]

[106] Kim J, Park JA, Lee EY, Lee YJ, Song YW, Lee EB. Imbalance of Th17 to Th1 cells in Behçet's disease. Clin Exp Rheumatol 2010; 28(4)(Suppl. 60): S16-9.

[PMID: 20868565] 
[107] Mathur AN, Chang HC, Zisoulis DG, et al. Stat3 and Stat4 direct development of IL-17-secreting Th cells. J Immunol 2007; 178(8): 4901-7. [http://dx.doi.org/10.4049/jimmunol.178.8.4901] [PMID: 17404271]

[108] Hou S, Yang Z, Du L, et al. Identification of a susceptibility locus in STAT4 for behçet's disease in han chinese in a genome-wide association study. Arthritis Rheum 2012; 64(12): 4104-13.

[http://dx.doi.org/10.1002/art.37708] [PMID: 23001997]

[109] Zervou MI, Goulielmos GN, Castro-Giner F, Boumpas DT, Tosca AD, Krueger-Krasagakis S. A CD40 and an NCOA5 gene polymorphism confer susceptibility to psoriasis in a Southern European population: A case-control study. Hum Immunol 2011; 72(9): 761-5. [http://dx.doi.org/10.1016/j.humimm.2011.05.014] [PMID: 21645569]

[110] Böser A, Drexler HC, Reuter H, et al. SILAC proteomics of planarians identifies Ncoa5 as a conserved component of pluripotent stem cells. Cell Reports 2013; 5(4): 1142-55.

[http://dx.doi.org/10.1016/j.celrep.2013.10.035] [PMID: 24268775]

[111] Rustemoglu A, Erkol Inal E, Inanir A, et al. Clinical significance of NCOA5 gene rs2903908 polymorphism in Behçet's disease. EXCLI J 2017; 16: 609-17.

[PMID: 28694762]

[112] Holm SJ, Carlén LM, Mallbris L, Ståhle-Bäckdahl M, O’Brien KP. Polymorphisms in the SEEK1 and SPR1 genes on 6p21.3 associate with psoriasis in the Swedish population. Exp Dermatol 2003; 12(4): 435-44. [http://dx.doi.org/10.1034/j.1600-0625.2003.00048.x] [PMID: 12930300]

[113] Rahman P, Butt C, Siannis F, et al. Association of SEEK1 and psoriatic arthritis in two distinct Canadian populations. Ann Rheum Dis 2005; 64(9): 1370-2.

[http://dx.doi.org/10.1136/ard.2004.031765] [PMID: 15708881]

[114] Bossini-Castillo L, Martin JE, Broen J, et al. Confirmation of TNIP1 but not RHOB and PSORS1C1 as systemic sclerosis risk factors in a large independent replication study. Ann Rheum Dis 2013; 72(4): 602-7. [http://dx.doi.org/10.1136/annrheumdis-2012-201888] [PMID: 22896740]

[115] Peddle L, Zipperlen K, Melay B, Hefferton D, Rahman P. Association of SEEK1 polymorphisms in Crohn's disease. Hum Immunol 2004; 65(7): 706-9. [http://dx.doi.org/10.1016/j.humimm.2004.04.002] [PMID: 15301859]

[116] Fan X, Yang S, Huang W, et al. Fine mapping of the psoriasis susceptibility locus PSORS1 supports HLA-C as the susceptibility gene in the Han Chinese population. PLoS Genet 2008; 4(3): e1000038.

[http://dx.doi.org/10.1371/journal.pgen.1000038] [PMID: 18369457]

[117] Reich K, Hüffmeier U, König IR, et al. TNF polymorphisms in psoriasis: Association of psoriatic arthritis with the promoter polymorphism TNF*-857 independent of the PSORS1 risk allele. Arthritis Rheum 2007; 56(6): 2056-64. [http://dx.doi.org/10.1002/art.22590] [PMID: 17530646]

[118] Ferrer-Admetlla A, Sikora M, Laayouni H, et al. A natural history of FUT2 polymorphism in humans. Mol Biol Evol 2009; $26(9)$ : $1993-2003$. [http://dx.doi.org/10.1093/molbev/msp108] [PMID: 19487333]

[119] Xavier JM, Shahram F, Sousa I, et al. FUT2: filling the gap between genes and environment in Behçet's disease? Ann Rheum Dis 2015; 74(3): 618-24. [http://dx.doi.org/10.1136/annrheumdis-2013-204475] [PMID: 24326010]

[120] Olzmann JA, Richter CM, Kopito RR. Spatial regulation of UBXD8 and p97/VCP controls ATGL-mediated lipid droplet turnover. Proc Natl Acad Sci USA 2013; 110(4): 1345-50. [http://dx.doi.org/10.1073/pnas.1213738110] [PMID: 23297223]

[121] Fei Y, Webb R, Cobb BL, Direskeneli H, Saruhan-Direskeneli G, Sawalha AH. Identification of novel genetic susceptibility loci for Behçet's disease using a genome-wide association study. Arthritis Res Ther 2009; 11(3): R66. [http://dx.doi.org/10.1186/ar2695] [PMID: 19442274]

[122] Sawalha AH, Hughes T, Nadig A, et al. A putative functional variant within the UBAC2 gene is associated with increased risk of Behçet's disease. Arthritis Rheum 2011; 63(11): 3607-12. [http://dx.doi.org/10.1002/art.30604] [PMID: 21918955]

[123] Hou S, Shu Q, Jiang Z, et al. Replication study confirms the association between UBAC2 and Behçet's disease in two independent Chinese sets of patients and controls. Arthritis Res Ther 2012; 14(2): R70. [http://dx.doi.org/10.1186/ar3789] [PMID: 22455605]

[124] Yamazoe K, Meguro A, Takeuchi M, Shibuya E, Ohno S, Mizuki N. Comprehensive analysis of the association between UBAC2 polymorphisms and Behçet's disease in a Japanese population. Sci Rep 2017; 7(1): 742-7. [http://dx.doi.org/10.1038/s41598-017-00877-3] [PMID: 28389674]

[125] Rallabhandi P, Hashimoto K, Mo YY, Beck WT, Moitra PK, D'Arpa P. Sumoylation of topoisomerase I is involved in its partitioning between nucleoli and nucleoplasm and its clearing from nucleoli in response to camptothecin. J Biol Chem 2002; 277(42): 40020-6. [http://dx.doi.org/10.1074/jbc.M200388200] [PMID: 12149243]

[126] Guo D, Li M, Zhang Y, et al. A functional variant of SUMO4, a new I kappa B alpha modifier, is associated with type 1 diabetes. Nat Genet 2004; 36(8): 837-41. 
[http://dx.doi.org/10.1038/ng1391] [PMID: 15247916]

[127] Hou S, Yang P, Du L, et al. SUMO4 gene polymorphisms in Chinese Han patients with Behcet's disease. Clin Immunol 2008; 129(1): 170-5. [http://dx.doi.org/10.1016/j.clim.2008.06.006] [PMID: 18657476]

[128] Kamoun M, Ben Dhifallah I, Karray E, Zakraoui L, Hamzaoui K. Association of small ubiquitin-like modifier 4 (SUMO4) polymorphisms in a Tunisian population with Behçet’s disease. Clin Exp Rheumatol 2010; 28(4)(Suppl. 60): S45-9. [PMID: 20868570]

[129] Park G, Kim HS, Choe JY, Kim SK. SUMO4 C438T polymorphism is associated with papulopustular skin lesion in Korean patients with Behçet's disease. Rheumatol Int 2012; 32(10): 3031-7.

[http://dx.doi.org/10.1007/s00296-011-2086-5] [PMID: 21901353]

[130] Sarkar B, Kulharia M, Mantha AK. Understanding human thiol dioxygenase enzymes: structure to function, and biology to pathology. Int J Exp Pathol 2017; 98(2): 52-66. [http://dx.doi.org/10.1111/iep.12222] [PMID: 28439920]

[131] Wilkinson DG, Bhatt S, Chavrier P, Bravo R, Charnay P. Segment-specific expression of a zinc-finger gene in the developing nervous system of the mouse. Nature 1989; 337(6206): 461-4.

[http://dx.doi.org/10.1038/337461a0] [PMID: 2915691]

[132] Nerlov C. The C/EBP family of transcription factors: A paradigm for interaction between gene expression and proliferation control. Trends Cell Biol 2007; 17(7): 318-24.

[http://dx.doi.org/10.1016/j.tcb.2007.07.004] [PMID: 17658261]

[133] Stanford SM, Bottini N. PTPN22: The archetypal non-HLA autoimmunity gene. Nat Rev Rheumatol 2014; 10(10): 602-11. [http://dx.doi.org/10.1038/nrrheum.2014.109] [PMID: 25003765]

[134] Oguro-Ando A, Zuko A, Kleijer KTE, Burbach JPH. A current view on contactin-4, -5, and -6: Implications in neurodevelopmental disorders. Mol Cell Neurosci 2017; 81: 72-83. [http://dx.doi.org/10.1016/j.men.2016.12.004] [PMID: 28064060]

\section{(c) 2018 Deng et al.}

This is an open access article distributed under the terms of the Creative Commons Attribution 4.0 International Public License (CC-BY 4.0), a copy of which is available at: (https://creativecommons.org/licenses/by/4.0/legalcode). This license permits unrestricted use, distribution, and reproduction in any medium, provided the original author and source are credited. 